\section{Correlation Between Volume of Root Canal, Cultivable Bacteria, Bacterial Complexes and Endotoxins in Primary Infection}

Flávia Goulart da Rosa Cardoso ${ }^{1,2} \mathbb{D}$, Frederico Canato Martinho ${ }^{1,3}$, Nádia de Souza Ferreira ${ }^{1,4}$, Renata Falchete do Prado ${ }^{1}$, Luiz Roberto Coutinho Manhães-Júnior ${ }^{5}$, Marco Antônio Rocco ${ }^{5}$, Marcia Carneiro Valera' 10

\author{
'Department of Restorative Dentistry, \\ Institute of Science and Technology, \\ UNESP - Univ Estadual Paulista, São \\ José dos Campos, SP, Brazil \\ ${ }^{2}$ Department of Dentistry, Endodontic \\ Division, University of Taubaté - \\ UNITAU, Taubaté, SP, Brazil \\ ${ }^{3}$ Department of Advanced Oral Science \\ \& Therapeutics, Endodontic Division, \\ University of Maryland, School of \\ Dentistry, Maryland, USA \\ ${ }^{4}$ Department of Semiology, UFPel \\ - Universidade Federal de Pelotas, \\ School of Dentistry, Pelotas, RS, Brazil \\ ${ }^{5}$ Department of Radiology, Institute \\ of Science and Technology, UNESP - \\ Univ Estadual Paulista, São José dos \\ Campos, SP, Brazil
}

Ccorrespondence: Dra. Marcia Carneiro Valera, Av. Eng. Francisco José Longo, 777, São José dos Campos, 12245-000 São Paulo, SP, Brazil. Tel: +55-123947-9400. Fax: +55-12-3947-9000. E-mail:marcia@fosjc.unesp.br

Key Words: bacteria, endotoxin, endodontic infection.

\section{Introduction}

Knowledge of the pathogenesis of endodontic infections is important for establishing therapeutic strategies (1). Special attempt has been given for the knowledge bacterial species and their association in complexes (2-5).

With the advances in molecular biology techniques have led to identification of new bacteria species and clones as well as detection of non-culturable species present in endodontic infections $(2,4)$. Studies have demonstrated a wide diversity of bacteria species, thus elucidating the polymicrobial profile involving both Gram-positive and Gram-negative bacteria species in endodontic infections $(2,4)$. Interactions of bacteria species and their grouping with complexes make endodontic infections even far more complex to the immune system response (6), which can lead to different clinical symptoms (5).

Socransky et al. (7) was the first to group bacteria species into complexes, thus simplifying their description and relationships between different microbial groups in the infections (i.e. red, green, orange, secondary orange, purple, yellow). Among the different complexes, the red bacterial complex, which includes Treponema denticola, Tannerella forsythia and Porphyromonas gingivalis, has been recognized as a 'disease-related' complex (8).
Particularly, their high prevalence has been associated with the development of symptoms and tooth mobility $(9,10)$.

The presence of clinical features has also been correlated with levels of lipopolysaccharides (LPS), also known as endotoxins. Such molecule is released during bacterial multiplication and cell death (11). Moreover, the levels of endotoxins in root canal infections are directly related to severity of periapical bone destruction (12-14).

Although some studies have speculated that a larger root canal holds higher levels of bacteria and a wider diversity of bacteria species due to the nutrients available in root canal environment and the synergism among bacteria species, in which the resulting metabolisms serve as nutrients for each species (15), no clinical study has addressed such correlations. These correlations should be demonstrated as the presence of micro-organisms in planktonic state or adhered to biofilms on the root canal wall are closely related to endodontic treatment failure $(16,17)$. Therefore, when choosing the instrumentation technique for root canal preparation, one should be aware of the shape and diameter of the files so that they can have maximum contact with the root canal walls, especially when they have greater volume.

This clinical study was conducted to correlate the levels 
of endotoxins and culturable bacteria found in primary endodontic infection (PEI) with the volume of root canal determined by using cone beam computed tomography (CBCT), as well as to evaluate the bacterial diversity correlating with clinical features.

\section{Material and Methods Ethical Approval}

This study was approved by the Research and Ethics Committee of São Paulo State University (UNESP), São José dos Campos, Brazil (179.380).

\section{Patient Selection}

Twenty patients treated at the São José dos Campos Dental School (São Paulo State University - UNESP), São José dos Campos (SP), Brazil, with PEl were included in the present study. A detailed dental history was obtained from each patient. Those who had received antibiotic treatment during the past three months or who had any general disease were excluded. The Human Research Ethics Committee of the São José dos Campos Dental School approved the protocol of the present research,

$$
\text { form }
$$
fo

\section{CBCT Analysis of Root Canal Volume}

The occlusal plane of the patient was oriented parallel to the axial scanning plane, according to the
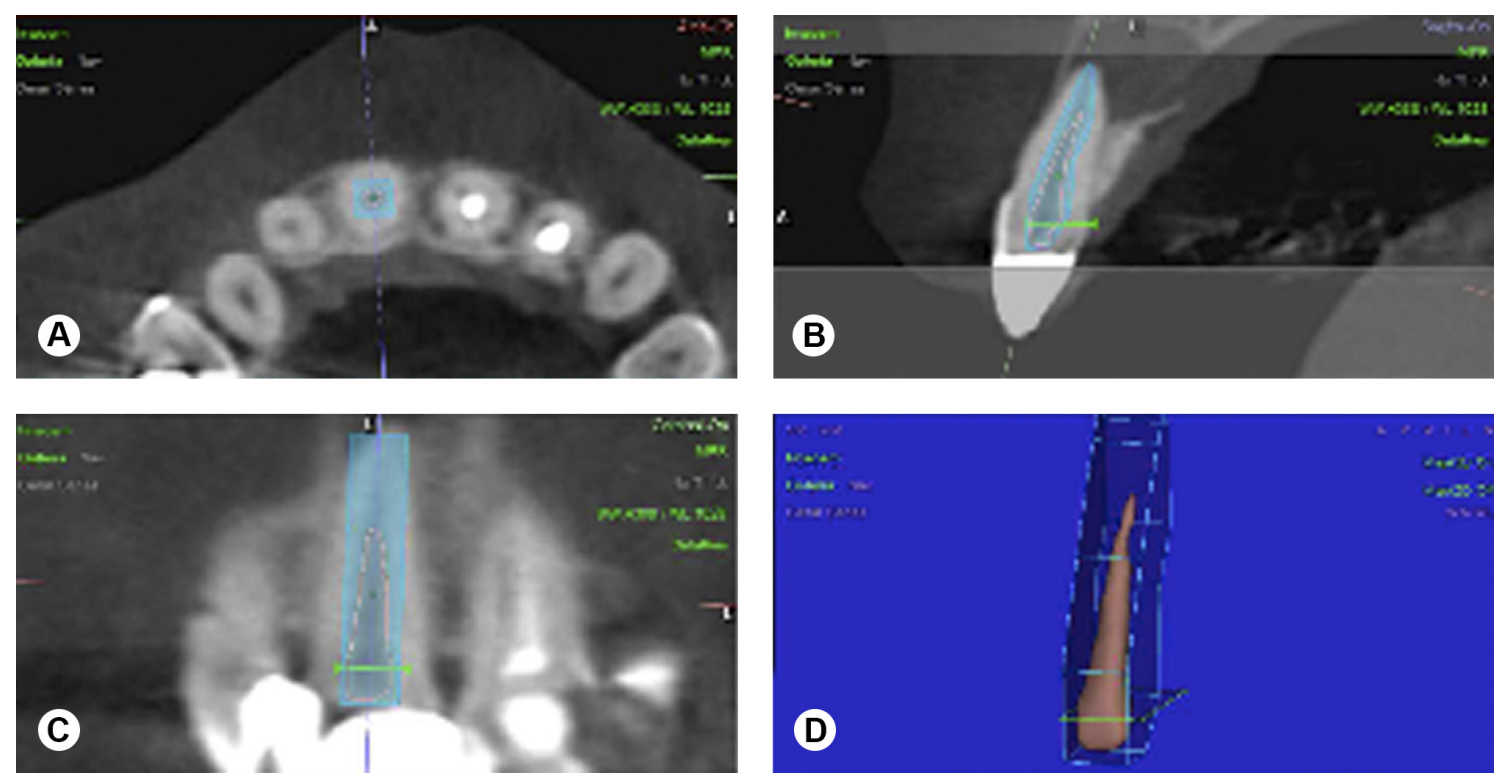

Figure 1. DICOM data of preoperative verification transferred to NEMOTEC software and 2D segmentation of root canal axial planes (A), sagittal planes (B) coronal planes (C) and 3D reconstruction root canal (D). 
detect" option of the software was used to automatically calculate the selected volumes in $\mathrm{cm}^{3}$. Then, the volume was converted into $\mathrm{mm}^{3}$ (Fig. 1).

\section{Root Canal Sampling Procedures}

Files, instruments, and all materials used in this study were treated with Co-60 gamma radiation (EMBRARAD; Empresa Brasileira de Radiação, Cotia, SP, Brazil) at 20 kGy for 6 hours for sterilization and elimination of preexisting endotoxins. The method used for disinfection of the operative field had been previously described elsewhere (14). Briefly, the teeth were isolated with a rubber dam and their crowns and surrounding structures were disinfected with $30 \% \mathrm{H}_{2} \mathrm{O}_{2}$ (volume/volume) for 30 seconds, followed by $2.5 \% \mathrm{NaOCl}$ for the same period of time and then inactivated with $5 \%$ sodium thiosulfate. The sterility of the external surfaces of the crowns was checked by taking a swab sample from the crown surface and streaking it onto blood agar plates, which were then incubated both aerobically and anaerobically. Colony formation was a criterion of exclusion.

A two-stage access cavity preparation was made without the use of water spray, but under manual irrigation with sterile/apyrogenic saline solution and by using sterile/ apyrogenic high-speed diamond bur. The first stage was performed to promote a major removal of contaminants, including carious lesion and restoration. In the second stage, before entering the pulp chamber, the access cavity was disinfected according to the protocol described above. Sterility of the internal surface of the access cavity was checked as previously described and all procedures were performed aseptically. A first endotoxin sample was taken by introducing sterile/apyrogenic paper points (size \#15, Dentsply-Maillefer, Balaigues, Switzerland) into the full length of the canal, which was determined radiographically, and retained in position during $60 \mathrm{~s}$ for sampling. Next, the sample was placed in a pyrogen-free glass and immediately suspended in $1 \mathrm{~mL}$ of limulus amebocyte lysate (LAL) water according to the endotoxin dosage by using kinetic chromogenic limulus amebocyte lysate (LAL) (Lonza, Walkersville, MD, USA) assay. This sampling procedure was repeated with 3 paper points pooled in a sterile tube containing $1 \mathrm{~mL}$ of VMGA III transport medium (18) for microbial culture.

\section{Quantification of Endotoxins}

The kinetic chromogenic limulus amebocyte lysate assay (Lonza, Walkersville, MD, USA) was used for quantification of endotoxins, with Escherichia coli endotoxin being used as standard. A positive control (root canal sample contaminated with a known amount of endotoxin) was included for each sample to determine the presence or absence of interfering agents. For the test, $100 \mu \mathrm{L}$ of apyrogenic water (reaction blank), five standard endotoxin solutions [0.005-50 endotoxin units $(\mathrm{EU}) / \mathrm{mL}]$, root canal samples, and positive controls (10 EU/mL) were added to a 96-well apyrogenic plate. The tests were carried out in quadruplicate. The plate was incubated at $37{ }^{\circ} \mathrm{C} \pm 1{ }^{\circ} \mathrm{C}$ for $10 \mathrm{~min}$ in a kinetic-OCL reader, which was coupled to a microcomputer by means of the WinKOCL software. Next, $100 \mu \mathrm{L}$ of chromogenic reagent was added to each well. After the beginning of the kinetic test, the software

Table 1. Strains used for the development of bacterial DNA probes

\begin{tabular}{|c|c|c|c|}
\hline Species & $\begin{array}{l}\text { ATCC } \\
\text { Strain }\end{array}$ & Species & $\begin{array}{l}\text { ATCC } \\
\text { Strain }\end{array}$ \\
\hline $\begin{array}{l}\text { Actinomyces } \\
\text { gerecseriae }\end{array}$ & 238060 & $\begin{array}{l}\text { Leptotrichia } \\
\text { bucallis }\end{array}$ & 14201 \\
\hline Actinomyces israelii & 12102 & Neisseria mисоsa & 19696 \\
\hline Actinomyces oris & 43146 & Parvimonas micra & 33270 \\
\hline $\begin{array}{l}\text { Actinomyces } \\
\text { odontolyticus }\end{array}$ & 17929 & $\begin{array}{l}\text { Porphyromonas } \\
\text { gingivalis }\end{array}$ & 33277 \\
\hline $\begin{array}{l}\text { Aggregatibacter } \\
\text { actinomycetemcomitans }\end{array}$ & $\begin{array}{c}43718+ \\
29523\end{array}$ & $\begin{array}{l}\text { Prevotella } \\
\text { intermedia }\end{array}$ & 25611 \\
\hline Campylobacter gracilis & 33236 & $\begin{array}{c}\text { Prevotella } \\
\text { melaninogenica }\end{array}$ & 25845 \\
\hline Campylobacter rectus & 33238 & $\begin{array}{l}\text { Prevotella } \\
\text { nigrescens }\end{array}$ & 33563 \\
\hline Campylobacter showae & 51146 & $\begin{array}{c}\text { Propionibacterium } \\
\text { acnes }\end{array}$ & 11827 \\
\hline $\begin{array}{l}\text { Capnocytophaga } \\
\text { gingivalis }\end{array}$ & 33624 & $\begin{array}{l}\text { Selenomonas } \\
\text { noxia }\end{array}$ & 43541 \\
\hline $\begin{array}{l}\text { Capnocytophaga } \\
\text { ochracea }\end{array}$ & 33596 & $\begin{array}{l}\text { Streptococcus } \\
\text { anginosus }\end{array}$ & 33397 \\
\hline $\begin{array}{l}\text { Capnocytophaga } \\
\text { sputigena }\end{array}$ & 33612 & $\begin{array}{l}\text { Streptococcus } \\
\text { constellatus }\end{array}$ & 27823 \\
\hline Eikenella corrodens & 23834 & $\begin{array}{l}\text { Streptococcus } \\
\text { gordonii }\end{array}$ & 10558 \\
\hline Enterococcus faecalis & 29212 & $\begin{array}{l}\text { Streptococcus } \\
\text { intermedius }\end{array}$ & 27335 \\
\hline Eubacterium nodatum & 33099 & $\begin{array}{l}\text { Streptococcus } \\
\text { mitis }\end{array}$ & 49456 \\
\hline Eubacterium saburreum & 33271 & $\begin{array}{l}\text { Streptococcus } \\
\text { oralis }\end{array}$ & 35037 \\
\hline $\begin{array}{l}\text { Fusobacterium } \\
\text { nucleatum spp. } \\
\text { polymorphum }\end{array}$ & 10953 & $\begin{array}{l}\text { Streptococcus } \\
\text { sanguinis }\end{array}$ & 10556 \\
\hline $\begin{array}{l}\text { Fusobacterium } \\
\text { nucleatum ssp. } \\
\text { nucleatum }\end{array}$ & 25586 & Tanerella forsythia & 43037 \\
\hline $\begin{array}{l}\text { Fusobacterium } \\
\text { nucleatum ssp. vicentii }\end{array}$ & 49256 & $\begin{array}{c}\text { Treponema } \\
\text { denticola }\end{array}$ & B1 \\
\hline $\begin{array}{l}\text { Fusobacterium } \\
\text { periodonticum }\end{array}$ & 33693 & $\begin{array}{l}\text { Treponema } \\
\text { socransckii }\end{array}$ & S1 \\
\hline Gemella morbillorum & 27824 & $\begin{array}{l}\text { Veillonella } \\
\text { parvula }\end{array}$ & 10790 \\
\hline
\end{tabular}


continuously monitored absorbance at $405 \mathrm{~nm}$ in each micro-plate well and automatically calculated the log/log linear correlation between reaction time of each standard solution and corresponding endotoxin concentration.

\section{Determination of CFU counts}

The method used for culture procedures in the present study had been previously reported by the author elsewhere (4). Briefly, the transport media containing the root canal samples were thoroughly shaken for 60 seconds (Vortex, Marconi, Piracicaba, SP, Brazil), with serial 10-fold dilutions being made up to $10^{-4}$ in tubes containing fastidious anaerobe broth (FAB, Lab M, Bury, UK). Equal volumes of serial dilutions were plated onto $5 \%$ defibrillated sheep blood fastidious anaerobe agar (FAA; Lab M) by using sterile plastic spreaders to culture non-selectively obligate anaerobes and facultative anaerobes. The plates were incubated at $37^{\circ} \mathrm{C}$ in anaerobic atmosphere for up to 14 days. After this period, colony-forming units were visually quantified for each plate.

\section{Determination of Bacterial Diversity}

Three hundred microliters of VMGA containing the root canal samples was transferred to another sterile tube. After this procedure, the tubes were centrifuged at 8000 rpm for 5 minutes. The supernatant was then discarded, and the pellet resuspended at $150 \mathrm{~mL}$ of Tris-EDTA buffer $(10 \mathrm{mmol} / \mathrm{L}$ of Tris [hydroxymethyl] aminomethane [Tris]$\mathrm{HCl}, 1 \mathrm{mmol} / \mathrm{L} \mathrm{EDTA}, \mathrm{pH}=7.6)$. Next, $100 \mathrm{~mL}$ of $0.5 \mathrm{~mol} / \mathrm{L}$ $\mathrm{NaOH}$ were added to each tube, and the samples were frozen at $-20^{\circ} \mathrm{C}$ until they were processed. Presence, levels, and proportions of 40 bacterial species (Table 1) were determined by using the checkerboard DNA-DNA hybridization method described by Socransky et al (7). The DNA probes were prepared by using the DIG DNA Labeling Kit (Roche Diagnostics, Indianapolis, IN, USA) and frozen until time of use (19). Next, the samples were boiled for 10 minutes, and $800 \mathrm{~mL}$ of $5 \mathrm{~mol} / \mathrm{L}$ ammonium acetate was added to promote bacterial lyses and consequent suspension of DNA in solution. A nylon membrane ( $15 \times 15$ $\mathrm{cm}$ ) with a positive charge (Hybond $\mathrm{N}+$; GE Healthcare Limited, Buckinghamshire, UK) was placed in a MiniSlot 30 apparatus (Immunetics, Cambridge, MA, USA), and $1000 \mathrm{~mL}$ of each suspension was placed into the extended slots of the MiniSlot 30 apparatus and fixed to the membrane by baking it at $120^{\circ} \mathrm{C}$ for 20 minutes. In each membrane, 28 samples were placed, and the last two channels of the MiniSlot 30 apparatus were reserved for placement of controls, containing a mixture of microorganism species being investigated by DNA probes at two concentrations (i.e., $10^{5}$ and $10^{6}$ ) of bacterial cells. A Miniblotter 45 apparatus (Immunetics) was used to hybridize the digoxigenin-labeled whole-genomic DNA probes perpendicular to the lanes of the clinical samples. Bound probes were detected with the use of phosphatase-conjugated antibodies to digoxigenin and chemiluminescence (CDP-Star Detection Reagent, GE Healthcare Limited). The membranes were placed under an X-ray film (AGFA-IBF, Duque de Caxias, RJ, Brazil) and left in position for approximately 60 minutes. The films were processed shortly thereafter. Each probe produced a certain type of signal, which was visually compared to the signal, which was visually compared to the signals produced by the probes in the two controls containing $10^{5}$ and $10^{6}$ bacterial cells. The signals were coded into six different classes in relation to the following count levels: 0 (not detected), 1 $\left(<10^{5}\right.$ cells), 2 (nearly $10^{5}$ cells), 3 (between $10^{5}$ and $10^{6}$ cells), 4 (approximately $10^{6}$ cells), and 5 ( $>10^{6}$ cells).

\section{Statistical Analysis}

Bacterial count (CFU/mL) was transformed into $\log ^{10}$ to obtain a normal distribution for Pearson's correlation and simple linear regression tests between anaerobic bacteria, root canal volume and endotoxins. Kruskal-Wallis tests were performed for analysis of quantitative data (CFU, endotoxins and root canal volume) and clinical qualitative data (spontaneous pain, sinus tract, exudates, pain on percussion and/or palpation). The bacterial DNA load was correlated with clinical features by using the Friedman's test.

\section{Results}

The following clinical features were found in teeth with PEl: pain on palpation (POP, 4/20), pain on percussion (TTP, 4/20), presence of sinus tract (ST, 6/20), exudates (EX, $2 / 20$ ) and previous episode of pain (PEP, 6/20). Bacteria and endotoxins were detected in $100 \%$ of the root canal samples (20/20) with median values of $8.4 \times 10^{5} \mathrm{CFU} / \mathrm{mL}$ $\left(7.4 \times 10^{5}-28.8 \times 10^{5} \mathrm{CFU} / \mathrm{mL}\right)$ and $17.45 \mathrm{EU} / \mathrm{mL}(21.2-103$ $\mathrm{EU} / \mathrm{mL}$ ), respectively. The median volume of root canal determined by CBCT analysis was $20 \mathrm{~mm}^{3}$ (10 to $40 \mathrm{~mm}^{3}$ ). The linear regression analysis revealed positive correlation between root canal volume and the bacterial load (R2 0.17, $\beta 0.01, p<0.05)$. Checkerboard DNA-DNA- hybridization indicated the most commonly bacteria species, namely: Fusobacterium ssp. vincentii (11/20), Streptococcus oralis (10/20) Porphyromonas gingivalis (9/20), Aggregatibacter actinomycetemcomitans (9/20), Eubacterium saburreum (9/20), Streptococcus anginosus (9/20), followed by Treponema socranskii (8/20) and Parvimonas micra (8/20).

Higher levels of $L$. buccalis, P. intermedia, $C$. gracilis, $C$. gingivalis, $C$. sputigena were found in cases of sinus tract $(p<0.05)$. C. ochracea was correlated with the presence of tenderness to percussion $(p<0.05)$. Positive correlations were found between interactions of secondary orange, green and red bacterial complexes with sinus tract $(p<0.05)$. 


\section{Discussion}

The results of this study revealed a positive correlation between root canal volume, determined by CBCT analysis, and CFU count found in PEI with apical periodontitis. The presence of selected bacteria species, such as L. buccalis, $P$. intermedia, C. gracilis, C. gingivalis and C. sputigena, as well as their interaction in the form of complexes, was positively correlated with the presence of clinical features.

The CBCT technology was used in this study to produce a three-dimensional reconstruction for quantification of the root canal volume. Our results have indicated a median volume of root canal of $20 \mathrm{~mm}^{3}$ (10 to $40 \mathrm{~mm}^{3}$ ). Additionally, the linear regression analysis has revealed a positive correlation between root canal volume and CFU count found in PEI with apical periodontitis. Over the years, clinical studies $(14,20,21)$ have correlated the size of periapical lesion with the bacterial load, but no study established a correlation between root canal volume and bacterial load encountered in root canal infections.

Checkerboard DNA-DNA hybridization has been of great advantage in this study; this multiplex method has been widely used in endodontics in order to screen for the most common bacteria species present in root canal (4). In this study, Checkerboard DNA-DNA- hybridization indicated high prevalence of Fusobacterium nucleatum ssp. vincentii, Streptococcus oralis, Porphyromonas gingivalis, Aggregatibacter actinomycetemcomitans, Eubacterium saburreum, and Streptococcus anginosus, followed by Treponema socranskii as well as Parvimonas micra (8/20). Such findings are in accordance with the literature, supporting the polymicrobial profile of PEI with participation of both Gram-positive and Gram-negative bacteria species. Higher levels of $L$. buccalis, P. intermedia, C. gracilis, $C$. gingivalis, $C$. sputigena were found in cases of sinus tract. In particular, $C$. ochracea was correlated with the presence of tenderness to percussion $(p<0.05)$. Positive correlations between different bacteria species and presence of clinical features have been demonstrated in endodontics (20). Sinus tract development depends on bone resorption and indicates necrosis of dental pulp, periapical suppuration or periodontal destruction of tooth, all leading to apical bone resorption (including buccal and lingual cortical plates) and affecting the mucoperiosteum, reaching the mucosal surface where it drains (22).

Socransky et al. (7) proposed to group bacteria species in order to simplify their description and relationships between the different microbial groups in the infections. Our study has demonstrated the interaction of different bacteria species, including orange secondary, green, and red bacterial complexes, with the presence of sinus tract. In particular, the green bacterial complex is comprised of C. sputigena, C. gingivalis, C. ochracea, E. corrodens and
A. actinomycetemcomitans, whereas the red bacterial complex includes $P$. gingivalis, $T$. denticola and $T$. forsythia. In particular, it was reported that red complex microorganisms may have a particular vigor to compete with other bacteria in the colonization of the root canal system, and their virulence factors may induce a stronger host immune response than other microorganisms (23).

It is worth pointing out that, although this study has shown a positive correlation between root canal volume and presence of culturable microorganisms, this relationship regarding microbial diversity was not found by using the checkerboard analysis. In this way, although larger root canals contain more microorganisms, the microbial diversity is similar to that found in smaller root canals.

It is known that endodontic treatments are currently performed with automated instrumentation, that is, rotary, reciprocating or hybrid instruments as well as techniques with multiple or single files (24). With the results found in this study, it becomes even clearer that it is important to choose the technique for enlarging the root canal. Larger root canals contain higher microbial load and probably more micro-organisms adhered to biofilms on the walls and their ramifications and dentinal tubules (16), thus demonstrating that it is extremely important to use instruments allowing all walls to be touched during the shaping and disinfection phases of the root canals. Moreover, one can associate supplementary steps to the root canal preparation, such as use of intra-canal medications or activation of auxiliary chemicals in order to maximize the elimination of microorganisms, which can enable better predictability of the success of endodontic treatment.

It has long been known that endotoxins released from Gram-negative bacteria in infected root canals can contribute to increasing vasoactive and neurotransmitter substances at the nerve endings in inflamed periapical lesions (11). This study quantified the levels of endotoxins in root canal infections by using LAL-assay, which has been widely used in endodontics (21). Among the different LAL tests (25), the kinetic chromogenic limulus amebocyte assay was used in this study to evaluate the levels of endotoxins in our samples. The kinetic chromogenic-LAL test (KOCL) reads the $\mathrm{OD}$ at multiple time points because the reaction proceeds with no termination step (60 minutes), which allows endotoxin concentration to be quantified over a wider range $(0.005-50 \mathrm{EU} / \mathrm{mL})$. The assay yielded a median value of endotoxins of $17.45 \mathrm{EU} / \mathrm{mL}$, similar to that found in previous investigation (14) using similar assay. Other study reported levels of endotoxins ranging from range, $0.010-10.4 \mathrm{EU} / \mathrm{mL}$ (26). Previous study demonstrated that higher levels of endotoxins were related to the development of symptoms, particularly the presence of previous pain (14) and other clinical signs such as pain on percussion and 
pain on palpation (27). However, such correlations were not addressed in this study.

In conclusion, this clinical study revealed that larger root canals hold higher levels of culturable bacteria in PEI. Thus, the interaction of different virulent bacteria species in complexes seems to play an important role in the development of clinical features.

\section{Resumo}

Este estudo clínico foi conduzido para correlacionar os niveis de endotoxinas e bactérias cultiváveis encontradas na infecção endodôntica primária (IEP) com o volume do canal radicular determinado pelo uso da Tomografia Computadorizada de Feixe Cônico (TCFC); e avaliar a diversidade bacteriana correlacionada com caracteristicas clínicas. Vinte pacientes com IEP foram selecionados e as características clínicas foram registradas. 0 volume $\left(\mathrm{mm}^{3}\right)$ do canal radicular foi determinado pela análise TCFC. As amostras do canal radicular foram analisadas usando o teste cinético de análise LAL para determinar os niveis de endotoxinas e técnicas anaeróbicas para determinar a contagem bacteriana (UFC/mL). 0 DNA foi extraido de todas as amostras para determinar a diversidade bacteriana e quantificado utilizando o teste Checkerboard-DNA-DNA-Hybridization. Bactérias cultiváveis e endotoxinas foram detectadas em 100\% das amostras do canal radicular. A análise de regressão linear revelou uma correlação entre o volume do canal radicular e a presença de bactérias anaeróbicas $(p<0,05)$. Foram encontradas correlações positivas entre espécies de bactérias e presença de diferentes características clínicas $(p<0,05)$. Após agrupamento das espécies dos micro-organismos em complexos bacterianos, foram encontradas associações positivas entre os complexos verde, laranja e vermelho com presença de fístula $(p<0,05)$. Este estudo clínico revelou que os canais radiculares mais amplos possuem niveis mais elevados de bactérias cultiváveis na IEP. Assim, a interação de diferentes espécies de bactérias virulentas em complexos parece desempenhar um papel importante no desenvolvimento de características clínicas.

\section{Acknowledgements}

The work was supported by the Brazilian agencies FAPESP (grant nos. 2014/25789-9).

\section{References}

1. Narayanan LL, Vaishnavi C. Endodontic microbiology. J Conserv Dent 2010; 13:233-239

2. Siqueira JF Jr., Alves FR, Roças IN. Pyrosequencing analysis of the apical root canal microbiota. J Endod 2011;37:1499-1503.

3. Anderson AC, Al-Ahmad A, Elamin F, Jonas D, Mirghani Y, Schihabel $M_{1}$ et al. Comparison of the bacterial composition and structure in symptomatic and asymptomatic endodontic infections associated with root-filled teeth using pyrosequencing. PLoS One 2013;8:e84960.

4. Ferreira NS, Martinho FC, Cardoso FG, Nascimento GG, Carvalho CA, Valera MC. Microbiological profile resistant to different intracanal medications in primary endodontic infections. J Endod 2015;41:824830.

5. Nobrega LM, Montagner F, Ribeiro AC, Mayer MA, Gomes BP. Bacterial diversity of symptomatic primary endodontic infection by clonal analysis. Braz Oral Res 2016;30:e103.

6. Ozbek SM, Ozbek A. Real-time polymerase chain reaction of "red complex" (Porphyromonas gingivalis, Tannerella forsythia, and Treponema denticola) in periradicular abscesses. Oral Surg Oral Med Oral Pathol Oral Radiol Endod 2010;110:670-674.

7. Socransky SS, Smith C, Martin L, Paster BJ, Dewhirst FE, Levin AE. "Checkerboard" DNA-DNA hybridization. Biotechniques 1994;17:788792.

8. Haffajee AD, Socransky SS, Patel MR, Song X. Microbial complexes in supragingival plaque. Oral Microbiol Immunol 2008:23:196-205.

9. Gomes BP, Montagner $F$, Jacinto RC, Zaia AA, Ferraz CC, Souza-Filho FJ. Polymerase chain reaction of Porphyromonas gingivalis, Treponema denticola, and Tannerella forsythia in primary endodontic infections. $J$ Endod 2007;33:1049-1052.

10. Roças IN, Siqueira JF Jr., Debelian GJ. Analysis of symptomatic and asymptomatic primary root canal infections in adult Norwegian patients. J Endod 2011;37:1206-1212.

11. Farber PA, Seltzer S. Endodontic microbiology. I. Etiology. J Endod 1988;14, 363-71.

12. Garcia de Aquino $S$, Manzolli Leite FR, Stach-Machado DR, Francisco da Silva JA, Spolidorio LC, Rossa C Jr. Signaling pathways associated with the expression of inflammatory mediators activated during the course of two models of experimental periodontitis. Life Sci 2009;84:745-754.

13. Martinho FC, Chiesa WM, Leite FR, Cirelli JA, Gomes BP. Antigenic activity of bacterial endodontic contents from primary root canal infection with periapical lesions against macrophage in the release of interleukin-1 beta and tumor necrosis factor alpha. J Endod 2010;36:1467-1474.

14. Cardoso FG, Ferreira NS, Martinho FC, Nascimento GG, Manhães Jr LR, Rocco MA, et al. Correlation between volume of apical periodontitis determined by cone-beam computed tomography analysis and endotoxin levels found in primary root canal infection. J Endod 2015;41:1015-1019.

15. Gomes BP, Lilley JD, Drucker DB. Variations in the susceptibilities of components of the endodontic microflora to biomechanical procedures. Int Endod J 1996;29:235-241.

16. Ricucci D, Siqueira JF. Biofilms and apical periodontitis: study of prevalence and association with clinical and histopathologic findings. J Endod 2010;36:1277-1288.

17. Siqueira JF, Roças IN. Present status and future directions in endodontic microbiology. Endod Topics 2014;30:3-22.

18. Moller AJ. Microbiological examination of root canals and periapical tissues of human teeth. Methodological studies. Odontol Tidskr 1966;74:1-380

19. Feinberg AP, Vogelstein B. A technique for radiolabeling DNA restriction endonuclease fragments to high specific activity. Anal Biochem 1983;132:6-13.

20. Martinho FC, Leite FR, Nascimento GG, Cirelli JA, Gomes BP. Clinical investigation of bacterial species and endotoxin in endodontic infection and evaluation of root canal content activity against macrophages by cytokine production. Clin Oral Investig 2014;18:2095-2102.

21. Cardoso FG, Chung A, Martinho FC, Camargo CH, Carvalho CA, Gomes $\mathrm{BP}$, et al. Investigation of bacterial contents from persistent endodontic infection and evaluation of their inflammatory potential. Braz Dent $J$ 2016;27:412-418.

22. Tai $T F$, Lin $C P$, $T$ sai $Y L$, Jeng JH. Sinus tracts from proximal roots with infected root canals - cases report. J Dent Sci 2016;1:202-206.

23. Buonavoglia A, Latronico F, Pirani C, Greco MF, Corrente M, Prati C. Symptomatic and asymptomatic apical periodontitis associated with red complex bacteria:clinical and microbiological evaluation. Odontology 2013;101:84-88

24. Cavalli D, Toia CC, Flores Orozco El, Khoury RD, Cardoso FGR, Alves MC, et al. Effectiveness in the removal of endotoxins and Microbiological profile in primary endodontic infections using 3 different instrumentation systems: a randomized clinical study. J Endod 2017;43:1237-1245.

25. Martinho FC, Chiesa WM, Zaia AA, Ferraz CC, Almeida JF, Souza-Filho $\mathrm{FJ}$, et al. Comparison of endotoxin levels in previous studies on primary endodontic infections. J Endod 2011;37:163-167.

26. Herrera DR, Silva EJ, Santos CC, Zaia AA, Ferraz CC, Almeida JF, et al. Root canal content from primary endodontic infection and up regulation of gelatinases in fibroblast cells. Int Endod J 2015;48:1168-1174.

27. Jacinto RC, Gomes BP, Shah HN, Ferraz CC, Zaia AA, Souza-Filho FJ. Quantification of endotoxins in necrotic root canals from symptomatic and asymptomatic teeth. J Med Microbiol 2005;54:777-783. 